\title{
Geomorphic Threshold and Landsliding in Paglajhora Sinking Zone, Darjiling Himalaya
}

\author{
Sujit Mondal \\ Associate Professorm, Department of Geography, Gour Banga University, Malda, NH-34; \\ West Bengal, India. \\ mandalsujit2009@gmail.com
}

\begin{abstract}
Assessment of geomorphic threshold is a significant parameter in landslide studies. The present study dealt with critical slope angle $\left(c_{\varphi}\right)$, critical rainfall $\left(c_{r}\right)$ and critical height $\left(c_{h}\right)$ of the Paglajhora Sinking Zone. This sinking zone is located in the representative mountain watershed, the Shiv-khola of Darjiling Himalaya, West Bengal. To estimate critical slope angle $\left(c_{\varphi}\right)$, a Mohr stress Diagram was developed using triaxial compression test parameters such as cohesion (c), major principal stress $\left(\sigma_{I}\right)$ and minor principal stress $\left(\sigma_{3}\right)$. Thickness of total soil $(h)$, thickness of saturated soil $(z)$, wet soil density $(P s)$, density of water $(P w)$ angle of repose $(\phi)$ and slope on scar face $(\theta)$ were assessed study the stability condition of the hill slope. The directional slope length and effective contour length were taken into account to determine upslope contributing area and critical rainfall $\left(c_{r}\right)$ of major landslide locations. The critical height $\left(c_{h}\right)$ was derived for the initiation of landslips incorporating cohesion (c), angle of internal friction $(\phi)$, unit weight of materials $(\gamma)$ and slope angle $(\theta)$.
\end{abstract}

Keywords: Paglajhora Sinking Zone, Critical slope, critical height and critical rainfall and geomorphic thresholds.

\section{INTRODUCTION}

Geomorphic threshold is significant parameters in analyzing the stability condition of particular spatial unit in a quantitative way. According to White et al., (1996) 'the minimum or maximum level of some quantity needed for a process to take place or a state to change is generally defined as threshold. Varnes (1978) studied the role of minimum intensity and duration of rainfall to cause a landslide of shallow soil slips, debris flows, debris slides or slumps. Crozier (1997) opined a maximum threshold, beyond which there is $100 \%$ chances of occurrences of the process at any time when the threshold value is exceeded. The most commonly investigated threshold parameters such as critical slope, critical slope height and critical rainfall (cumulative rainfall, antecedent rainfall, intensity and duration of rainfall) in relation to landslide phenomena has been attempted to identify in the present study. Starkel (1972) for the first time, observed the geomorphic effects of an extreme rainfall event in the eastern Himalaya (Darjiling), India. Froehlich et al., (1990) investigated the same area and found that shallow slides and slumps on steep slope segments occur when 24 hours rainfall reaches $130-150 \mathrm{~mm}$ or continuous three days rainfall totals 180-200 mm. Campbell, 1975; Cotecchia, 1978; Caine, 1980; Innes, 1983; Pomeroy, 1984; Canon and Ellen, 1985; Keefer et al., 1987; Kim et al., 1991; Li and Wang, 1992; Larsen and Simon, 1993; Wilson et al., 1995; Wieczorek, 1987, 1996, 2000; Terlien, 1997, 1998; Crosta, 1998; Crozier, 1999; Glade et al., 2000; Aleotti, 2004; Guzzetti et al., 2004, 2007; Hong et al., 2005; and Zezere et al., 2005 tried to establish rainfall-intensity thresholds for predicting the slope failure accurately. Caine (1980) first established worldwide rainfall threshold values for landslides. Montgomery and Dietrich (1994) introduced a physically based model for the topographic control on shallow landsliding in terms of geomorphic threshold. Recently Guzzetti et al., (2007) reviewed rainfall thresholds for the initiation of landslides worldwide and proposed new empirical thresholds based on the statistical analysis of the relationship between rainfall and landslide occurrences. They defined intensity-duration threshold as:

$\mathrm{I}=73.90 \mathrm{D}^{-0.79}$

Where, I is the hourly rainfall intensity in millimeters ( $\mathrm{mm} \mathrm{hr}-1)$ and $\mathrm{D}$ is duration in hours. 
Brunsden et al., 1981; Wagner 1983; Manandhar and Khanal, 1988; Dhital et al., 1993; Upreti and Dhital, 1996; Gerrard and Gardner, 2000; Dhital, 2003; Dahal et al. 2006a, while other works, such as Caine and Mool (1983), and Dhakal et al. (1999) focused mainly on landslide risk assessment in Himalayan terrains by analyzing physical properties of landslides and debris flows, effects of regional and local geological settings, and recommendations for environmental-friendly preventive measures.

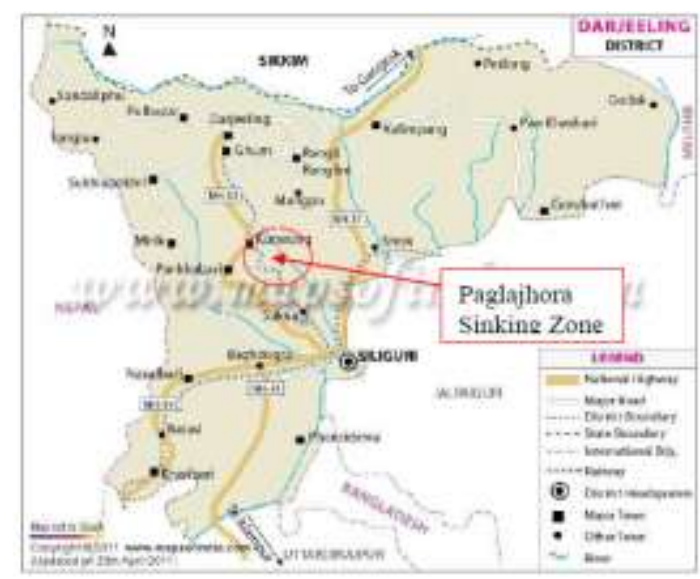

Figure1. Location of Paglajhora Sinking Zone in Darjiling District.

In the Shivkhola watershed, the physical processes and human actions (formation of road-cut benches and concentration of human settlement) are active on the slope in a systematic interactive combination by anthropogenic processes which make the slope steeper than repose angle varying from $19^{0}$ to $23^{0}$ with an average of $21^{\circ}$ and thus the instability is introduced into the system. The present study attempts to identify/determine the critical values of rainfall, slope height and slope angle beyond which there is a greater probability of slope instability in Pglajhora sinking zone of the Shivkhola Watershed (Figure1). The formation of road-cut benches to develop communication network lengthens the steep slope, removes the lateral and basal support, and disturbs the soil, favours infiltration and throughflow, helping in the increase of wet soil depth. All those change and their combined manifold aftereffects help to generate geomorphic threshold and the shear stress to increase over shear strength. Sometimes, moderate levels of rainfall for few days in the basin become more critical because of weak lithological composition. Moreover, the concentration of human settlement and development of communication lines generates enormous pressure on slope materials and favours threshold values by reducing the shearing strength. The study shows that only $88.928 \mathrm{~mm}$ daily rainfall is the critical rain for initiation of slide at Paglajhora. So there is every possibility for the generation of geomorphic threshold for initiation of slide due to hydrologic factor. In this way, there is a frequent occurrence of debris slide which reduces the slope angle on landslide scar face to that of repose angle to attain temporary stability through internal feed back in a process of homeostatic adjustment.

Study involves the measurement of upslope contributing area, contour length, slope angle, transmissivity, depth of soil, depth of the saturated soil, density of water, wet soil density, unit weight of the materials, pore-water pressure, cohesion, and angle of repose for the determination of 'intrinsic threshold' (Schumm,1977) condition such as critical slope angle, critical rainfall and critical slope height beyond which slope materials may undergo chemical decomposition and thereby lose its former strength and the slope may collapse without an extrinsic type of threshold being crossed. The response to threshold crossing may induce dramatic erosion and striking changes of the concerned landforms which is shaped primarily by the disturbances rather than by normal events. The recoveries of such disturbances are often a long and slow process which is mainly accomplished through Selforganized Feed Back Mechanism in the geomorphic system.

- Mallet opined (1874), in the Darjeeling territory the "Gondwana" rocks are overlain by the metamorphic rocks, which are termed as "Darjeeling Geniss" (mainly mica-gneisses and Schists) and "Daling" (mainly slates and phyllites). Darjiling gneiss and Chungtang formation (upper part of Daling) aer associated basically covered the Paglajhora Sinking area. These two lithological units composed of highly foliated gneiss, mica-schists and occasional bands of flaggy quartzites and granulitic rocks, slates phyllites with occasional quartzite, quartz-schists and greywake schists (Figure 2) 


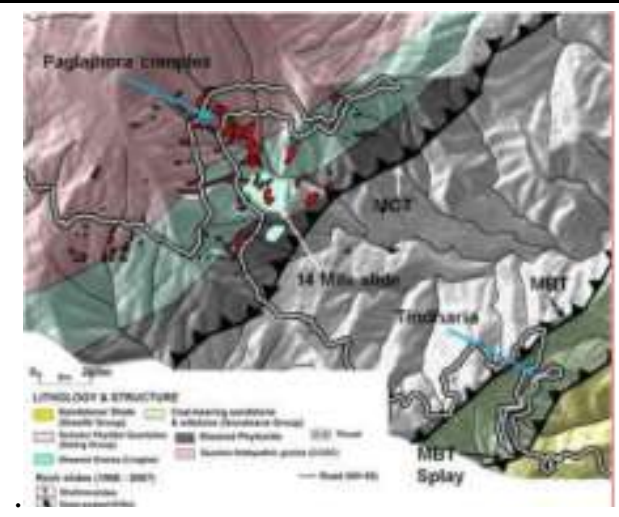

Figure2. Location of Paglajhora with lthology and structure (Ghosh et al. GSI)

mylonitised granite with sub-parallel thrust, phyllite, silvery-mica-chlorite-schist, grey sericite, and Slate phyllite with quartzite, quartz-schist \& greywake schist. The zone is characterized by the following structurally controlled phenomena.

$>$ Seepage through heavily disintegrated and decomposed materials and formation of clay minerals, which induces slope instability.

$>$ Rocks are traversed by quartz and quartzo-felspathic veins and the rocks are often highly metamorphosed and jointed.

$>$ Recrystallisation and cataclastic deformation have destroyed the clastic texture with intense granulation along narrow zones of fracture.

$>$ The apexes of the sliding zones are predominated with good amount of organic matter which encourages high water holding capacity and volume expansion.

$>$ The apexes of the sliding zones are deforested and are susceptible to both sheet and gully erosion.

In the Paglajhora Sinking zone the heavily disintegrated fragile lithology makes the slope more vulnerable to landslip. Starkel (1972) for the first time, observed the geomorphic effects of an extreme rainfall event in the eastern Himalaya (Darjiling), India. Froehlich et al., (1990) investigated the same area and found that shallow slides and slumps on steep slope segments occur when 24 hours rainfall reaches $130-150 \mathrm{~mm}$ or continuous three days rainfall totals $180-200 \mathrm{~mm}$.
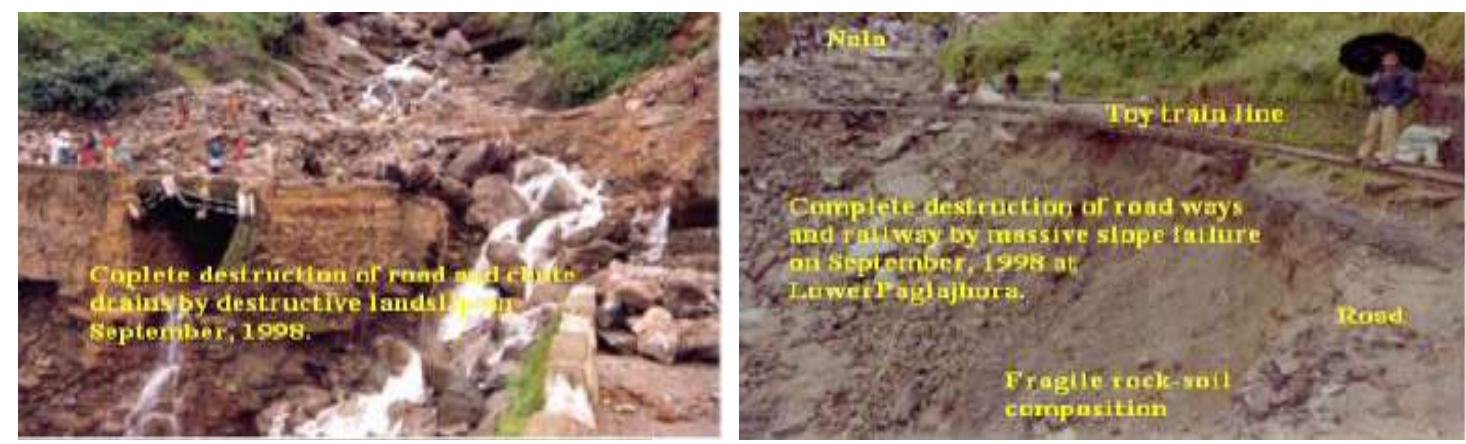

Plate1. Destructive failure in Paglajhor Sinking Zone (1998), Plate2. Destruction of toy train at Paglajhora

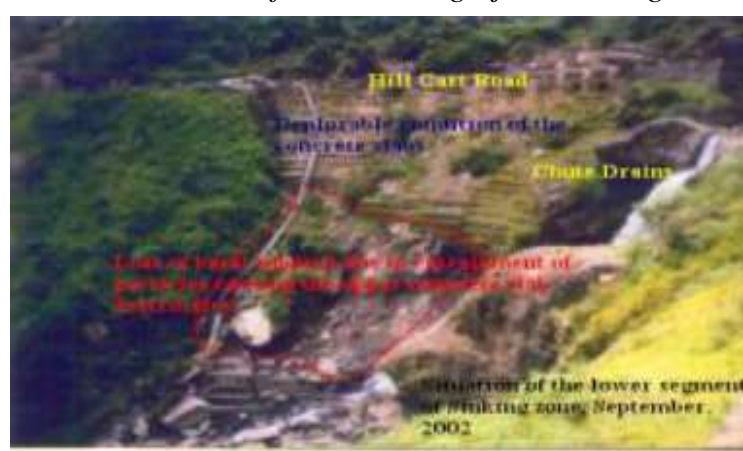

Plate3. Downslope subsidence in 2002.

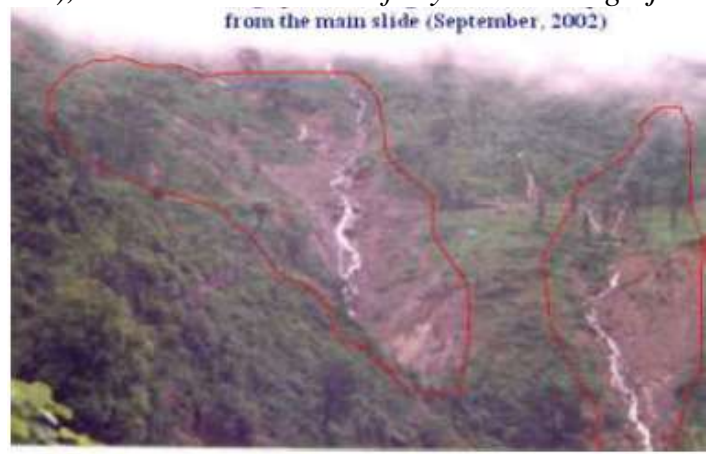

Plate4. Fresh landslides in Paglajhora (2002). 


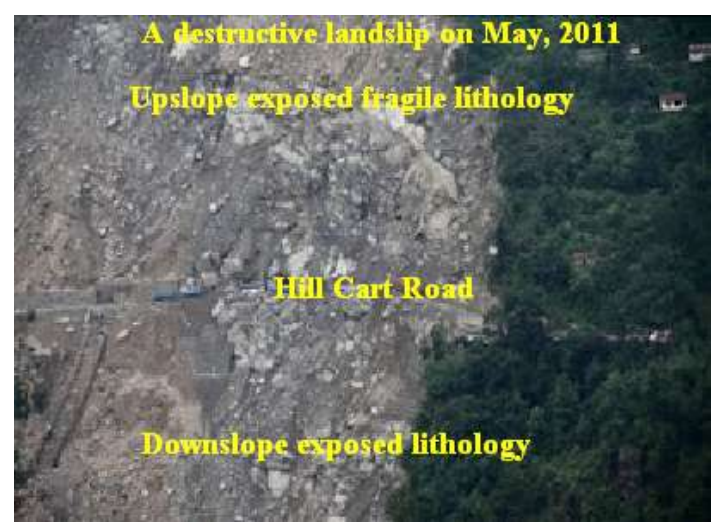

Plate5. Road side failure at Paglajhora (2009)

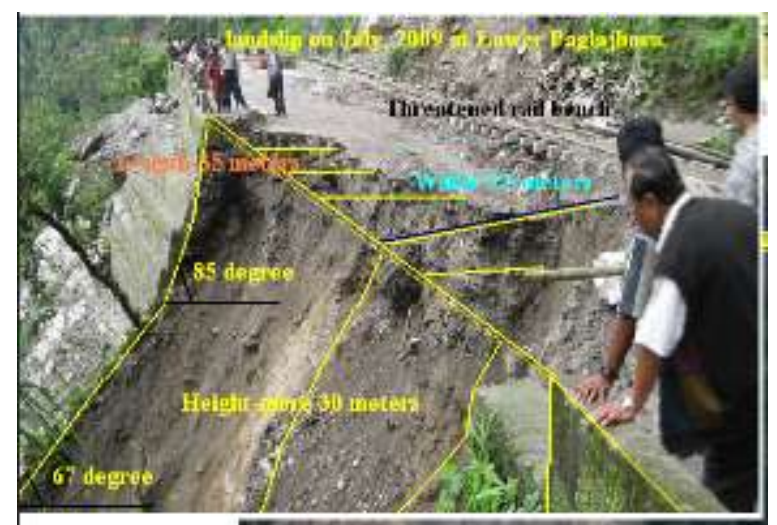

Plate6. A complete distruction in paglajhora(2011)

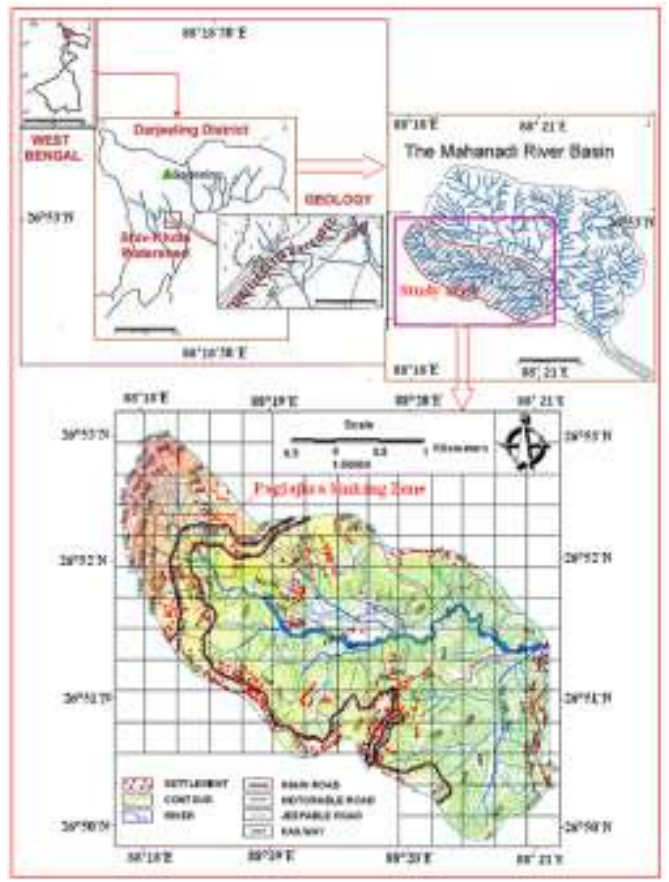

Figure5. Location of Paglajhor Sinking Zone in the Shivkhola watershed.
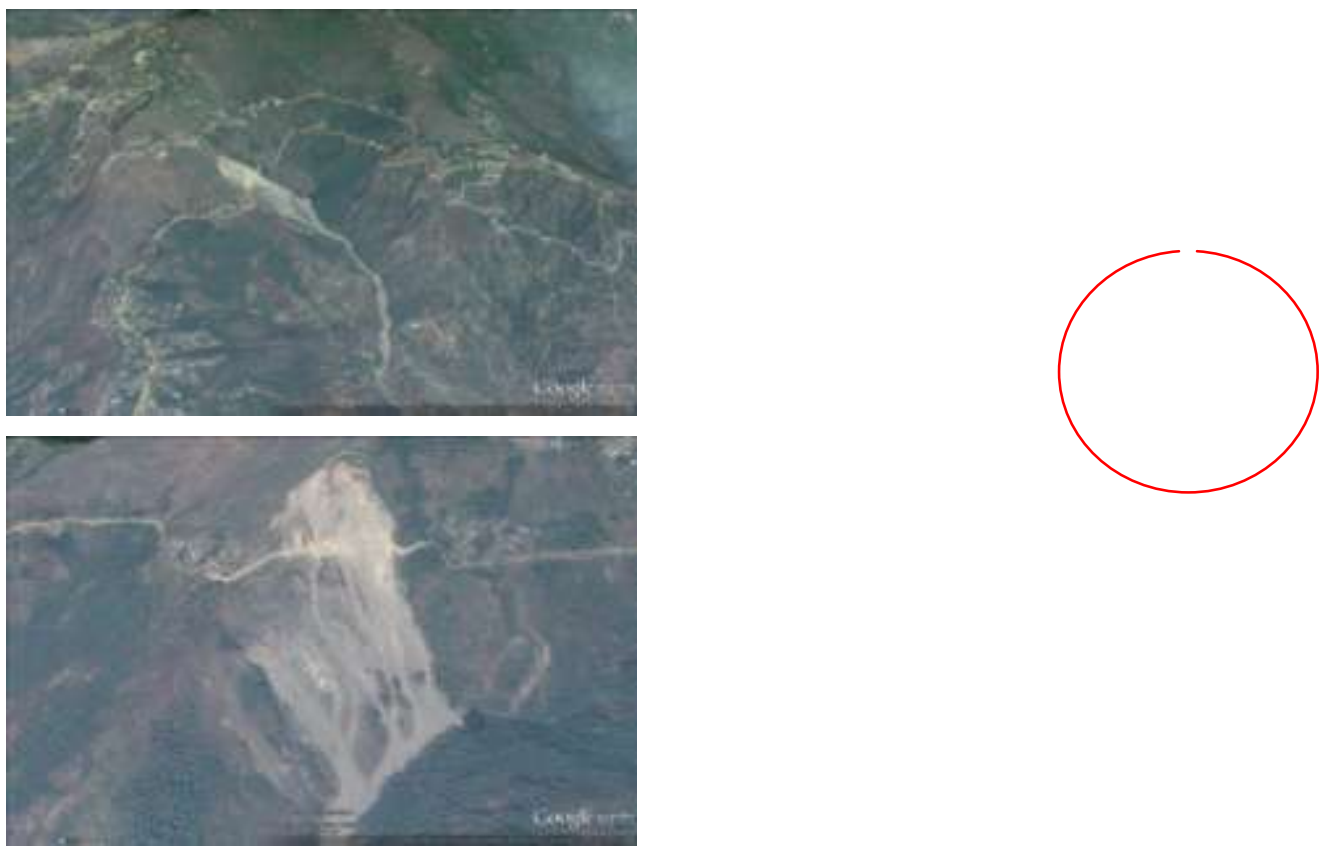

Figure4. Landslide in June, 2015 at Paglajhora. Figure 4: View Landslide in June, 2015 at Paglajhora. 


\section{Materials ANd Method}

\subsection{Determination of Angle of internal friction ( $\varphi$ ) and Cohesion (c) and Transmissivity (T)}

The geo-technical factor like angle of repose of the debris is measured after Bloom (1991) and Pethick (1984). The tangent of angle of repose of dry granular materials is slightly greater than, but approximately equals to the co-efficient of sliding friction of the material or its mass friction $(\phi)$ (Van Burkalow, 1945 and Bloom, 1991). The cohesion and angle of internal friction is measured by tri-axial compression test following Mohr stress Diagram. Major Principal Stress and minor principal stress were measured from GSI Soil Laboratory to estimate cohesion and friction angle. A Mohr Stress Circle was developed to obtain angle of internal friction and angle of rupture through $\sigma_{3}$ and $\sigma_{1}$ with the centre on the horizontal axis; the centre of the circle was obviously $\left(\sigma_{1}+\sigma_{3}\right) / 2$ and the radius was $\left(\sigma_{1}-\sigma_{3}\right) / 2$. The values of confining pressure, $\sigma_{3}$, and compressive stress, $\sigma_{1}$ were plotted on horizontal axis where stress difference is $\sigma_{1}-\sigma_{3}$. On a plane parallel to the greatest principal stress axis $(2 \alpha=0)$ the normal stress across the plane was $\sigma_{3}$ and the shearing stress was 0 . If the plane makes an angle of $45^{0}$ with the greatest principal stress axis $(2 \alpha=90)$, the shearing stress is at a maximum and the normal stress is $\left(\sigma_{1}+\sigma_{3}\right) / 2$. If the plane makes an angle of $90^{\circ}$ with the greatest principal stress axis $(2 \sigma$ $\left.=180^{\circ}\right)$, the shearing stress is 0 and the normal stress is $\sigma_{1}$.

In this way a series of experiments were being accomplished with different values of confining pressure $\left(\sigma_{3}\right)$. The Mohr Circle shows that as the confining pressure is increased, the stress as well as the stress difference must be increased to produce rapture. A line which is the tangent of the 'Mohr Circle' is called as the 'Mohr Envelope'. The angle that this line makes with the horizontal axis of the diagram is the angle of internal friction, $\varphi$. The saturated conductivity of the sail varies from $10^{-2} \mathrm{~m} \mathrm{~s}$ ${ }^{1}$ for the soil depth less than $0.5 \mathrm{~m}$ to $10^{-5} \mathrm{~m} \mathrm{~s}^{-1}$ for soil depth between 1 to $2 \mathrm{~m}$ (Fenti, 1992). Based on these and other data, Matteotti (1996) estimated the transmissivity (T) of saturated soil to lie between 5 and $30 \mathrm{~m}^{-2}$ day ${ }^{-1}$, with a mean value of $15 \mathrm{~m}^{-2}$ day ${ }^{-1}$ (Borga et.al 1998) and considering the mean value of transmissivity $(\mathrm{T})$ threshold parameters were assessed.

\subsection{Determination of Threshold Slope Angle for Initiation of Slide}

The formation of road-cut benches introduces the steep back slope and the slope on the landslide scar is greater than the angle of repose. This situation is mainly responsible for instability. The stability equation for a mass of loose, friable cohesion less debris after Melnikov and Chesnokov (1969) is as following.

\begin{tabular}{|c|c|}
\hline Shear Stress & $W \operatorname{Cos} \theta \operatorname{Tan} \phi$ \\
\hline Safety Factor $=$ & - \\
\hline Shear Strength & $W \operatorname{Sin} \theta$ \\
\hline or. $\underline{\operatorname{Tan} \phi}>1$ & \\
\hline or, $\overline{\operatorname{Tan} \theta} \geq 1$ & \\
\hline
\end{tabular}

\section{3. i.e.[(Angle of Repose/Angle of Internal Friction) $\geq$ (Slope on scar face)]}

Where, Tan $\phi=$ Co-efficient of friction; $\varphi=$ Angle of repose; $W=$ Weight of Soil and $\theta=$ Slope on Scar face.

The average slope angle of Paglajhora is $53^{\circ} 20^{\prime}$ ' which always outweighs the angle of repose. The other indefinite slope stability model for cohesion less material and slope parallel seepage after (Borga et. al. 1998) also supports the equation 4.

$$
\frac{h}{z}=\frac{P s}{P w}\left(1-\frac{\operatorname{Tan} \theta}{\operatorname{Tan} \phi}\right)>1
$$

Where, $\mathrm{h}=$ Thickness of Total Soil; $\mathrm{z}=$ Thickness of Saturated Soil; Ps=Wet Soil Density; Pw= Density of Water; $\phi=$ Angle of Repose; and $\theta=$ Slope on Scar Face.For maintaining the stability ' $h$ ' is needed to be 
greater than ' $z$ ' and $\left(1-\frac{\operatorname{Tan} \theta}{\operatorname{Tan} \phi}\right)$ should be positive.

So $\left(1-\frac{\operatorname{Tan} \theta}{\operatorname{Tan} \phi}\right)$ -

Or, $\left(1 \geq \frac{\operatorname{Tan} \theta}{\operatorname{Tan} \phi}\right)$

Or, $\operatorname{Tan} \phi \geq \operatorname{Tan} \theta$ Or $\phi \geq \theta$

(Angle of Repose) $\geq$ (Slope on Scar face).

\section{SATURATEd SoIl DePTH}

The depth of the failure surface was measured by holding a measuring tape at both the margins of scar and the other tape was allowed to hang, the reading was then taken from the base of the hanging tape. The margin of the scars was surveyed by prismatic compass. The intensive survey of the sliding scar for 50 different landslide locations was carried on by Abney's level at $0.5 \mathrm{~m}$ interval along radial lines originating from lower most part of the scar. The altitude of the points at $0.5 \mathrm{~m}$ interval along the radial lines is then estimated using Sine rule in reference to the central base point of known altitude determined by GPS (Basu and Maiti, 2001 and Maiti, 2007). The total thickness of soil and that of saturated soil for 50 sites during monsoon were measured from slope cutting. After estimating the approximate depth of all known points, a soil depth map (z/D) was made using Arc GIS tool.

\subsection{Unit weight of the soil (W), Wet soil density (Ps) and density of water (Pw)}

The unit weight of the soil (W), Wet Soil Density (Ps), Density of Water (Pw) were estimated following 'Keen Box Methods' and examining the soil samples collected from 50 landslide locations in the study area. Specific unit weight of water and unit weight of the soil were estimated by examining the soil samples collected from 50 landslide locations during field investigation from the GSI (Geological Survey of India, East Kolkata) laboratory. The density of soil and water varies from place to place due to in situ geo-hydrologic condition.

\subsection{Upslope Contributing area (uca)}

Upslope Contributing Area (UCA) is an effective indicator of drainage concentration over space. The place having more contributing area encompasses more soil saturation and reduces soil cohesion. The specific contributing area (total contributing area divided by the contour length) is computed by distributing flow from a pixel among its entire lower elevation neighbour pixel (Borga et.al., 1998). Quinn et al. (1991) proposed that the Fraction of Flow $\left(\mathrm{F}_{\mathrm{i}}\right)$ allocated to each lower neighbour (i) is determined by using equation-1.

An upslope contributing area map was prepared based on calculated contributing area value for each $(0.25$ sq.km) grid and it was divided into 6 equal classes.

$F i=\frac{\text { SiLi }}{\Sigma \text { SiLi }}$

[Where, the summation $(\Sigma)$ is for the entire lower neighbor, $\mathrm{S}$ is the directional slope, and $\mathrm{L}$ is an effective contour length that acts as the weighting factor. The value of $\mathrm{L}$ used here is $10 \mathrm{~m}$ of the pixel size of the cardinal neighbour and $14.14 \mathrm{~m}$ of the pixel diagonal for diagonal neighbor].

\subsection{Threshold rainfall to initiate landslip}

Campbell, 1975; Caine, 1980; Larsen and Simon, 1993 established that the empirical threshold condition to initiate landslide refers to relational value based on statistical analysis of the relationship between rainfall and landslide occurrences where as the physical thresholds are usually determined with the help of hydrologic and stability models that take into consideration of various attributes such as transmissivity $(T)$, wet soil density $\left(\mathrm{p}_{\mathrm{s}}\right)$, density of water $\left(\mathrm{p}_{\mathrm{w}}\right)$, slope angle $(\theta)$, angle of internal friction $(\phi)$, relation between rainfall and pore-water pressure etc. In the absolutely unstable condition the role of rainwater to initiate the threshold for sliding could be determined. If the hydrological 
factors like rain fall and seepage flow are considered the threshold condition for absolute instability can be predicted. The critical rainfall $\left(\mathrm{r}_{\mathrm{cr}}\right)$ after Borga et.al. 1998 following equation no 8.

$$
\begin{aligned}
& \mathrm{b} \mathrm{p}_{\mathrm{s}} \quad \operatorname{Tan} \theta \\
& r_{c r}=T \sin \theta---[1-------[\text {--------------------- } \\
& \mathrm{a} \mathrm{p}_{\mathrm{w}} \quad \operatorname{Tan} \phi
\end{aligned}
$$

\section{The Return Period of the threshold Rainfall}

The return period of the Total of the Catastrophic Rainfall and Average daily rain of catastrophic days is calculated on the basis of the duration of the period 2005 - 2010 following Gumbel, 1954 (Table.6.5) and using the following formula.

$\mathrm{T}=(\mathrm{N}+1) / \mathrm{m}$

(Gumbel, 1954)

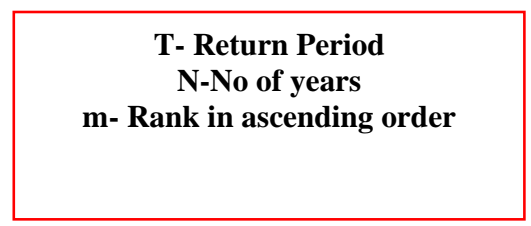

\section{The determination of recurrence interval of the Catastrophic Rainfall}

The calculation of recurrence interval of the Total of the Catastrophic Rainfall and Average daily catastrophic rain of days recording more than the calculated threshold rain is done by log probability law following Chow, 1962, 1964 and Schwab et.al. 2002.

$$
\mathrm{Xc}=\mathrm{x}(1+\mathrm{CvK})
$$

$$
\begin{aligned}
& \text { Xc - Calculated Rainfall } \\
& \text { x - mean value } \\
& \text { Cv - Coefficient of variation } \\
& \text { K- Log Probality Frequency Factor (calculated from } \\
& \text { the table of Chow, 1964) }
\end{aligned}
$$

\subsection{Threshold Slope Height to Initiate Slide}

Skempton (1953) and Skempton and Hutchinson (1969) in their experience in the development of steep slope and its evolution through slides in the glacial till of County Durham found a critical slope height of $45 \mathrm{~m}$ at $30-35^{\circ}$ steepness. Terzaghi (1962) calculated the critical slope height of the cliff at which failure occurs. In the present study critical height for slope failure is determined after Cullman (1866) and Carson (1977).

$$
\begin{aligned}
\mathrm{h}_{\mathrm{c}}= & 4 \mathrm{c}^{\prime} \operatorname{Sin} \theta \operatorname{Cos} \phi \\
-\gamma & 1-\operatorname{Cos}(\theta-\phi)
\end{aligned}
$$

Where, $\mathrm{h}_{\mathrm{c}}=$ Critical (Threshold) Slope Height; $\mathrm{c}^{\prime}=$ Cohesion; $\phi=$ Angle of Internal Friction; $\gamma=$ Unit Weight of Materials; $\theta=$ Slope Angle.

\subsection{Result and Discussion}

The investigation with the temporal change in the slide scar reveals that the slope evolution is subjected to a complex interaction between physical and anthropogenic processes. The human action in various developmental activities leads to the development of geomorphic threshold in the form of slope steepness, slope height and threshold rainfall. The estimated geo-technical parameters of the sample collected from the Paglajhora Sinking Zone is summarized in table no.1.

The thickness of the soil and that of the saturated soil during monsoon are measured to be $7.25 \mathrm{~m}$ at Lower Paglajhora. 


\section{Sujit Mondal}

The wet soil buck density is measured to be $1.96 \mathrm{~g} / \mathrm{cc}$ and density of water is $1.07 \mathrm{~g} / \mathrm{cc}$ applying Keen Box method.

Table1. Calculated geotechnical parameters of two major landslide locations

\begin{tabular}{|l|l|l|}
\hline Sl. No. & Parameters & Lower Paglajhora \\
\hline 1 & Major Principal Stress (Kg./sq Cm.) & 1.83 \\
\hline 2 & Minor Principal Stress (Kg./sq Cm.) & 0.76 \\
\hline 3 & Normal Stress (Kg./sq Cm.) & 1.10 \\
\hline 4 & Angle of Rupture (Degree) & $35^{\circ} 30^{\prime}$ \\
\hline 5 & Angle of Internal Friction (Degree) & $21^{\circ}$ \\
\hline 6 & Cohesion (Kg./sq Cm.) & 0.06 \\
\hline 7 & Shear Strength (Kg./sq Cm.) & 0.5 \\
\hline
\end{tabular}

\subsection{Critical Slope for the initiation of landslideat Paglajhora Sinking Zone}

The angle of internal friction varies from $21^{0}$ to $26^{0}$ with an average of $24^{0}$. The spatial distribution of threshold slope depicts that basic requirement for the short term stability of the slope at marginal escarpment slope of Lower Paglajhora to maintain the slope angle of nearer or less than $21^{0}$. A steep slope would decline by slope failure to an angle of repose slope to attain short term stability.

\subsection{Threshold Rainfall and landsliding at Paglajhora}

The calculated critical rainfall of Tindharia and Lower Paglajhora are $105.88 \mathrm{~mm} /$ day and $88.93 \mathrm{~mm} /$ day respectively (Table.2).

Table2. Critical rainfall ( $\mathrm{mm} /$ day) for setting instability (Borga et.al., 1998).

\begin{tabular}{|l|l|l|l|l|l|l|l|l|}
\hline Location & Transmissivity (T) & Slope $(\theta)$ & $\begin{array}{l}\text { Contour } \\
\text { length }(\mathrm{m})\end{array}$ & $\begin{array}{l}\text { Run-off } \\
\text { area } \\
\text { sq.m. }\end{array}$ & $\begin{array}{l}\text { Wet soil } \\
\text { density }\end{array}$ & $\begin{array}{l}\text { Density of } \\
\text { water }\end{array}$ & $\begin{array}{l}\text { Friction } \\
\text { angle }\end{array}$ & $\begin{array}{l}\text { Critical } \\
\text { Rainfall } \\
(\mathrm{mm})\end{array}$ \\
\hline $\begin{array}{l}\text { Lower } \\
\text { Paglajhora }\end{array}$ & $15 \mathrm{~m}^{-2}$ day $^{-1}$ & $48^{0} 20^{\prime}$ & 22.00 & 968 & $1.96 \mathrm{~g} / \mathrm{cc}$ & $1.96 \mathrm{~g} / \mathrm{cc}$ & $21^{0}$ & $\mathbf{8 8 . 9 2 8}$ \\
\hline
\end{tabular}

A relationship between antecedent cumulative rainfall and landslide vents of 1993, 1998, 2003, 2007 and 2010 was established on the basis of the data recorded from earlier research work done by Ghosh et al. (2009b); Basu et al. (2000) and the collection of rainfall data from nearby Selim Hill Tea Estate by author himself. The 1998 landslide event took place due to $300-600 \mathrm{~mm}$ cumulative rainfall in the past $2 / 3$ days only. The two days' antecedent cumulative rainfall was $390 \mathrm{~mm}$ was responsible for 1998 landslide events. The major event of 2003 happened due to incessant rainfall of $500 \mathrm{~mm}$ in 2 days. $17^{\text {th }}$ and $18^{\text {th }}$ July, 2007 received rainfall of $124.5 \mathrm{~mm}$ and $100 \mathrm{~mm}$ respectively. These two days' antecedent cumulative rainfall of $224.5 \mathrm{~mm}$ caused havoc slope failure at Upper and Lower Paglajhora. Again 2007 faced landslide events on $8^{\text {th }}$ September when $6^{\text {th }}, 7^{\text {th }}$ and $8^{\text {th }}$ September's antecedent cumulative rainfall amount was $275 \mathrm{~mm}$. In 2010, major and prominent landslide events happened as a result of 5 days' rainfall of $345 \mathrm{~mm}$ at 14 Mile near lower Paglajhora. Antecedent Cumulative rainfall induced landslide analysis shows that the continuous and uniform rate of minimum amount of rainfall (approx. less than $80 \mathrm{~mm} /$ day) for few consecutive days can cross the geomorphic threshold and can introduce slope instability condition.

\subsection{Average Catastrophic Rainfall since 2005 to 2010 at Paglajhora}

The Selim Hill Tea Estate situated $250 \mathrm{~m}$ North West of the study area registered 52 days having more than the critical rain fall to initiate threshold condition during last six years between 2005-2010 (Table.3). The determined average rainfall for the 2005, 2006, 2007, 2008, 2009, and 2010, are 120.7 mm., $127 \mathrm{~mm}$., $128.5 \mathrm{~mm}$., $161.12 \mathrm{~mm} ., 141.53 \mathrm{~mm}$ and $102.4 \mathrm{~mm}$ respectively which are greater than the estimated threshold rainfall from Lower Paglajhora. 
Table3. Analysis of catastrophic rainfall event during 2005 - 2010.

\begin{tabular}{|c|c|c|c|c|c|c|c|c|c|c|c|}
\hline 2005 & Rain in $\mathbf{m m}$ & 2006 & $\begin{array}{l}\text { Rain } \\
\text { in } \mathbf{~ m m} \\
\end{array}$ & 2007 & $\begin{array}{l}\text { Rain in } \\
\text { mm }\end{array}$ & 2008 & $\begin{array}{l}\text { Rain in } \\
\text { mm }\end{array}$ & 2009 & $\begin{array}{l}\text { Rain in } \\
\text { mm }\end{array}$ & 2010 & $\begin{array}{l}\text { Rain in } \\
\text { mm }\end{array}$ \\
\hline $20^{\text {th }}$ June & 95.5 & $23^{\text {rd }}$ May & 103.5 & $10^{\text {th }}$ June & 222.72 & $7^{\text {th }}$ June & 125 & 3rd June & 146.5 & $24^{\text {th }}$ May & 88.9 \\
\hline $26^{\text {th }}$ June & 183.5 & $28^{\text {th }}$ July & 150 & $28^{\text {th }}$ June & 93.5 & $9^{\text {th }}$ June & 100 & $19^{\text {th }}$ June & 133 & $28^{\text {th }}$ May & 101.6 \\
\hline 31 ${ }^{\text {st }}$ July & 134.5 & $29^{\text {th }}$ July & 160 & $29^{\text {th }}$ June & 120.5 & $23^{\text {rd }}$ June & 203 & 7th July & 175 & $16^{\text {th }}$ June & 111.7 \\
\hline $3 \mathrm{rd} \mathrm{Oct}$ & 100 & $30^{\text {th }}$ July & 112.5 & 10th July & 120 & $26^{\text {th }}$ June & 179 & 12th July & 200.5 & 14th July & 103.6 \\
\hline \multirow[t]{8}{*}{$4^{\text {th }}$ Oct } & 90 & $19^{\text {th }}$ Aug & 150 & 17thJuly & 124.5 & $29^{\text {th }}$ June & 196.5 & $9^{\text {th }}$ Sep & 98.7 & 18th July & 102 \\
\hline & & 31st Aug & 120.5 & $18^{\text {th }}$ July & 100 & 7th July & 273.5 & ${ }^{27 \text { th }}$ Sep & 95.5 & 25th July & 92.4 \\
\hline & & $17^{\text {th }}$ Sep. & 89.5 & 27thJuly & 120.5 & 8th July & 162.5 & & & $5^{\text {th }}$ Aug & 114.3 \\
\hline & & 3rd Oct & 130 & $18^{\text {th }}$ Aug & 145.5 & 21st July & 146.5 & & & $25^{\text {th }}$ Aug & 89.4 \\
\hline & & & & 23rd Sep. & 106.2 & 28th July & 148.5 & & & $28^{\text {th }}$ Aug & 102.6 \\
\hline & & & & & & 30th July & 100 & & & 16thSep. & 115.5 \\
\hline & & & & & & $10^{\text {th }}$ Aug & 191.5 & & & 25thSep. & 116.3 \\
\hline & & & & & & $31^{\text {st }}$ Aug & 107.5 & & & 26thSep. & 90.5 \\
\hline No of Days & 5 & & 8 & & 9 & & 12 & & 6 & & 12 \\
\hline Total & 603.5 & & 1016 & & 1153.42 & & 1933.5 & & 849.2 & & 1228.8 \\
\hline Average & 120.7 & & 127 & & 128.15 & & 161.12 & & 141.53 & & 102.4 \\
\hline
\end{tabular}

Source: Selim Hill Tea Estate (1/2 km. Crow fly dist. from the studied locations).

\section{Return period of Rainfall at Paglajhora}

The total catastrophic rain of more than the calculated threshold value of the year 2005 has a return period of 7 years and the average catastrophic daily rain of more than the calculated threshold rain that received in 2005 can be experienced with a recurrence interval of 7 years (Table.4).

Table.4:Return Period of Catastrophic Rainfalls after Gumbel, 1954.

\begin{tabular}{|c|c|c|c|c|c|c|c|c|c|}
\hline Year & \begin{tabular}{|l|} 
No of Days \\
of \\
Catastrophic \\
Rainfall \\
\end{tabular} & $\begin{array}{l}\text { Total of the } \\
\text { Catastrophic } \\
\text { Rainfall }\end{array}$ & $\begin{array}{l}\text { Arranged } \\
\text { in } \\
\text { descending } \\
\text { order }\end{array}$ & Rank & $\begin{array}{l}\mathrm{T}=(\mathrm{N}+1) / \mathrm{m} \\
(\text { Gumbel , 1954) }\end{array}$ & $\begin{array}{l}\text { Average } \\
\text { daily } \\
\text { rain }\end{array}$ & \begin{tabular}{|l|} 
Arranged in \\
descending \\
order
\end{tabular} & Rank & $\begin{array}{l}\mathrm{T}=(\mathrm{N}+1) / \mathrm{m} \\
(\text { Gumbel } \\
\text {,1954) }\end{array}$ \\
\hline 2005 & 5 & 603.5 & 1933.5 & 1 & 7 & 120.7 & 161.12 & 1 & 7 \\
\hline 2006 & 8 & 1016 & 1228.8 & 2 & 3.5 & 127 & 141.53 & 2 & 3.5 \\
\hline 2007 & 9 & 1153.42 & 1153.42 & 3 & 2.33 & 128.15 & 128.15 & 3 & 2.33 \\
\hline 2008 & 12 & 1933.5 & 1016 & 4 & 1.75 & 161.12 & 127 & 4 & 1.75 \\
\hline 2009 & 6 & 849.2 & 849.2 & 5 & 1.4 & 141.53 & 120.7 & 5 & 1.4 \\
\hline 2010 & 12 & 1228.8 & 603.5 & 6 & 1.16 & 102.4 & 102.4 & 6 & 1.16 \\
\hline Mean & & & 1130.7367 & & & \begin{tabular}{|l|}
130.150 \\
0
\end{tabular} & & & \\
\hline $\begin{array}{l}\text { Std } \\
\text { Deviation }\end{array}$ & & & 452.7617 & & & 19.8087 & & & \\
\hline $\begin{array}{l}\text { Coefficient } \\
\text { of Variation }\end{array}$ & & & 0.4000415 & & & $\begin{array}{l}0.15219 \\
9\end{array}$ & & & \\
\hline
\end{tabular}

\section{Probabilistic Recurrence Interval of Rainfall}

The daily average catastrophic rain (more than the calculated threshold) that can be experienced at a recurrence interval of 20 years (with 5\% probability) is 164.97 and that at a recurrence interval of 5 years (with $20 \%$ probability) is 131.793 (Table.5).

Table.5: Amount of Rain fall at Certain Probability and with specific return period (After Chow, 1951 and 1954).

\begin{tabular}{|l|l|l|l|}
\hline $\mathrm{P} \%$ & $\mathrm{~T}$ (Years) & $\mathrm{K}$ & Xc $(\mathrm{mm})$ \\
\hline $\mathbf{9 9}$ & $\mathbf{1 . 0 1}$ & $\mathbf{- 2 . 0 0 1}$ & $\mathbf{9 0 . 5 3 9}$ \\
\hline $\mathbf{5 0}$ & $\mathbf{2}$ & $\mathbf{- 0 . 0 8 3}$ & $\mathbf{1 2 8 . 5 0 7}$ \\
\hline $\mathbf{2 0}$ & $\mathbf{5}$ & $\mathbf{0 . 0 8 3}$ & $\mathbf{1 3 1 . 7 9 3}$ \\
\hline $\mathbf{5}$ & $\mathbf{2 0}$ & $\mathbf{1 . 7 5 9}$ & $\mathbf{1 6 4 . 9 7 1}$ \\
\hline 1 & $\mathbf{1 0 0}$ & $\mathbf{2 . 6 6 9}$ & $\mathbf{1 8 2 . 9 8 5}$ \\
\hline
\end{tabular}

The calculation shows that $88.928 \mathrm{~mm}$ daily rainfall is the threshold rain for Paglajhora and the analysis of return period shows that $120.7 \mathrm{~mm}$ daily rainfall can occur at a recurrence interval of 1.4 years following Gumbel, 1954 and $128.507 \mathrm{~mm}$ daily rain has a recurrence interval of 2 years with $50 \%$ probability following Chow, 1951 and 1954. That means there is every possibility for the generation of geomorphic threshold for initiation of slide due to hydrologic factor. At Paglajhora the critical rainfall is $88.93 \mathrm{~mm}$ which is less than the estimated rainfall of $90.54 \mathrm{~mm}$ at the recurrence 
interval of 1.01 year with $99 \%$ probability. So it can be inferred that Paglajhora is a place of higher probability of rainfall triggering landslide phenomena in every rainy season.

\section{Calculated Critical Height in landsliding at Paglajhora}

The determined critical slope height after Cullman, 1866 and Carson, 1971 of the places Lower Paglajhora is $7.80 \mathrm{~m}$. The height of the vertical back wall along the road should be restricted to almost $6.00 \mathrm{~m}$. in Paglajhora. The landslide affected area in Darjiling Himalaya with more than $6.00 \mathrm{~m}$ height corresponding to the average threshold slope angle of $21^{0}$ to $24^{0}$ must be identified and shaped to that of safe height (below $6.00 \mathrm{~m}$.). It is observed that the physical and anthropogenic processes are active on slope in an interactive combination. Construction of road and associated deforestation destabilize soil and slope. Slope is steepened, soil becomes loose and friable, lateral support is removed, soil becomes saturated by hydrological intervention. All these together leads to instability and threshold condition are achieved. Ultimately slope failure occurs and that helps to achieve temporary stability in the mountain terrain.

Table9. Critical Height for initiation of slide at two major landslide locations.

\begin{tabular}{|c|c|c|}
\hline Sl. No. & Slope Parameters & Lower Paglajhora \\
\hline 1 & Upslope Contributing area (a) & $968 \mathrm{~m}^{2}$ \\
\hline 2 & Contour length (b) & $22 \mathrm{~m}$ \\
\hline 3 & Slope angle $(\Theta)$ & $48^{0} 20^{\prime}$ \\
\hline 4 & Angle of Internal Friction $(\varphi)$ & $21^{0}$ \\
\hline 5 & Transmissivity $(\mathrm{T})$ & $\begin{array}{l}15 \mathrm{~m}^{-2} \text { day } \\
\text { (Borga et.al 1998). }\end{array}$ \\
\hline 6 & Wet soil buck density $\left(\mathrm{P}_{\mathrm{s}}\right)$ & $1.96 \mathrm{~g} / \mathrm{cc}$ \\
\hline 7 & Density of water $\left(\mathrm{P}_{\mathrm{W}}\right)$ & $1.07 \mathrm{~g} / \mathrm{cc}$ \\
\hline 8 & Cohesion (Kg. /sq Cm.) & 0.06 \\
\hline 9 & 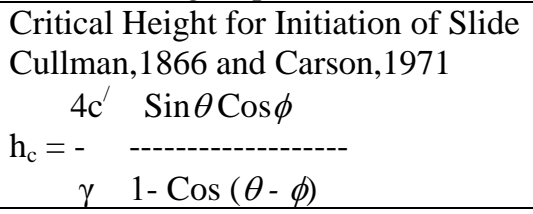 & $7.80 \mathrm{~m}$ \\
\hline
\end{tabular}

\section{CONClusion}

Slope map of the watershed reveals that it varies from very gentle gradient (around $10^{\circ}$ ) in the mid central \& mid-lower part to that of high (more than $60^{\circ}$ ), towards the marginal part/water divide. The major landslide locations are registered with the slope angle ranges between $40^{\circ}$ and $60^{\circ}$. The study depicts the positive relationship between the slope steepness and the occurrences of landslide phenomena in the Paglajhora area. Analysis states that more than $60 \%$ area of the Sinking zone experiences above average threshold slope angle of $24^{0}$. The lineaments at the places of Lower Paglajhora are closely spaced. The study depicts that the all the physiographic parameters of the soil changes the geomorphic threshold and initiate slope instability. In Paglajhora area, the physiographic configuration along with fragile lithology, drainage concentration, and moderate to steep slopes create favourable environment for landslips. Not only that the area is intersected by number of first order streams which helps seepage and slope materials saturation and consequently reduces cohesion and shear strength of slope materials and finally promote slope failure.

\section{REFERENCES}

Aleotti, P. (2004) A warning system of rainfall-induced shallow failure. Engineering Geology, 73, 247-265.

Basu et al. (2000) Geology of Darjeeling in Rain, Landslides and Floods in the Darjeeling Himalaya (Ed.) Starkel Leszek and Basu Subhas Ranjan.pp.-12-16.

Bloom, A. L. (1991) Geomorphology, a systematic analysis of the Cenozoic Landforms, New Delhi, Prentice Hall of India Pvt. Ltd. (pp. 76-177).

Borga et al. (1998) Shallow Landslide hazard assessment using a physically based model and digital elevation data. Journal of Environmental Geology, 35(2-30): 81-88.

Brunsden, D., Jones, D.K.C., Martin, R.P., Doornkamp, J.C., (1981) The geomorphological character of part of the Low Himalaya of Eastern Nepal. Z. Geomorph. N.F. Suppl.-Bd. 37, $25-72$. 
Caine, N. (1980) The rainfall intensity-duration control of shallow landslides and debris flows. Geografiska Annaler 62A, 23-27.

Caine, N. and Mool, P.K. (1982) Landslides in the Kolpu Khola Drainage, Middle Mountain, Nepal. Mountain Research and Development 2, 157-173.

Campbell, R.H. (1975) Soil slips, debris flows, and rainstorms in the Santa Monica Mountains and vicinity, Southern California. US Geol. Surv. Prof. Paper, vol. 851, pp. 1-20.

Cannon, S.H. and Ellen, S.D. (1985) Rainfall conditions for abundant debris avalanches, San Francisco Bay region, California. Geology 38 (12), 267-272.

Carson, M. A. (1977) Angles of repose, angles of shearing resistance at angle of talus slopes, Earth surface Processes 2, pp. $363-380$.

Chow, V.T. (ed.1964) Handbook of Applied Hydrology, Mc Grow-Hill Book CO., Lac, New York,N.Y.

Chow, V.T. (1962) Hydrologic Determination of Waterway Areas for the Design of Drainage Structures in Small Drainage Basins. III. Eng. 12, pp. 571-572.

Cotecchia, V. (1978) Systematic reconnaissance mapping and registration of slope movements. Bull. Int. Ass. Eng. Geol. 17, 5-37.

Crosta, G. (1998) Regionalization of rainfall threshold: an aid to landslide hazard evaluation. Environmental Geology 35 (2-3), 131-145.

Crozier, M.J. (1997) The climate-landslide couple: a southern hemisphere perspective. In: Matthews, J.A., Brunsden, D., Frenzel, B., Glaeser, B., Weiss, M.M. (Eds.), Rapid mass movement as a source of climatic evidence for the Holocene. Gustav Fischer Verlag, Stuttgart, pp. 333-354.

Crozier, M. J. (1999) Prediction of rainfall-triggered landslides: a test of the antecedent water status model. Earth Surface Processes and Landforms 24, 825-833.

Dahal, R.K., Hasegawa, S., Masuda, T., Yamanaka, M. (2006a) Roadside slope failures in Nepal during torrential rainfall and their mitigation, In: Marui, H., Marutani, T., Watanabe, N., Kawabe, H., Gonda, Y., Kimura, M., Ochiai, H., Ogawa, K., Fiebiger, G., Heumader, J., Rudolf-Miklau, F., Kienholz, H. and Mikos, M. (Eds.), Proc. Interpraevent Int. Symp, Niigata 2006, Disaster mitigation of debris flow, slope failures and landslides, Universal Academy Press, Tokyo, vol. 2, pp. 503-514.

Dhakal, A.S., Amada, T.K., Aniya M. (1999) Landslide hazard mapping and application of GIS in the Kulekhani Watershed, Nepal, Mountain Research and Development 19(1), 3-16.

Dhital, M.R., Khanal, N., Thapa, K.B. (1993) The role of extreme weather events, mass movements, and land use changes in increasing natural hazards, A Report of the preliminary field assessment and workshop on causes of recent damage incurred in southcentral Nepal, July 19-20 1993. ICIMOD, Kathmandu, 123 pp.

Dhital, M. R. (2003) Causes and consequences of the 1993 debris flows and landslides in the Kulekhani watershed, central Nepal. In: Rickenmann, D., Chen, C.-L. (Eds.), Proc. 3rd Intl. conf. debris-flow hazards mitigation: mechanics, prediction and assessment, Millpress, Rotterdam, Netherlands, vol. 2, pp. 931-942.

Fenti, V. (1992) Indagini geologic-techniche sull' area del dispositivo di misura (in Italian) in Marchi L. (ed) II Basino attrezzato del Rio Cordon, Quadevni di Ricerca, n. 13, Ragione Veneto. Dipartimento Foreste, Venezia Mestre: (pp. 109-122).

Froehlich, W. Gil, E., Kasza I., Starkel, L. (1990) Thresholds in the transformation of slopes and river channels in the Darjeeling Himalaya, India. Mountain Research and Development 10(4), 301312 .

Gerrard, J., Gardner, R.A.M. (2000) Relationships between rainfall and landsliding in the Middle Hills, Nepal. Norsk geogr. Tidsskr. 54, 74-81.

Glade, T., Crozier, M., Smith, P. (2000) Applying probability determination to refine landslidetriggering rainfall thresholds using an empirical Antecedent Daily Rainfall Model. Pure and Applied Geophysics 157, 1059-1079. 
Gumbel, E.J. (1954). Statistical Theory of Extreme Values and Some Practical Applications. Applied Mathematics Series 33. U.S. Bureau of Standards, Washington, DC.

Guzzetti, F., Cardinali, M., Reichenbach, P., Cipolla, F., Sebastiani, C., Galli, M., Salvati, P. (2004) Landslides triggered by the 23 November 2000 rainfall event in the Imperia Province, Western Liguria, Italy. Engineering Geology 73, 229-245.

Guzzetti, F., Peruccacci, S., Rossi, M., Stark, C.P. (2007) Rainfall thresholds for the initiation of landslides in central and southern Europe. Meteorol. Atmos. Phys., online first version, DOI 10.1007/s00703-007-0262-7 (accessed on 2007-08-07).

Hong et al. (2005) The influence of intense rainfall on the activity of large scale crystalline schist landslides in Shikoku Island, Japan, Landslides, 2: 97-105.

Innes, J.L. (1983) Debris flows. Prog Phys Geog 7, 469-501.

Keefer, D.K., Wilson, R.C., Mark, R.K., Brabb, E.E., Brown, W.M., Ellen, S.D., Harp, E.L., Wieczorek, G.F., Alger, C.S., Zatkin, R.S. (1987) Real-time warning during heavy rainfall. Science 238(4829), 921-925.

Kim, S.K., Hong, W.P., Kim, Y.M. (1991) Prediction of rainfall triggered landslides in Korea. In: Bell, D.H. (Ed.), Landslides, Rotterdam: A.A. Balkema, vol. 2, pp. 989-994.

Larsen, M.C. and Simon, A. (1993) A rainfall intensity-duration threshold for landslides in a humidtropical environment, Puerto Rico. Geografiska Annaler 75(1-2), 13-23.

Li, T. and Wang, S. (1992) Landslide hazards and their mitigation in China, Science Press, Beijing, 84 $\mathrm{pp}$.

Maiti, R. (2007) Identification of Potential Slope Failure Zones of Shiv-Khola Watershed; Darjiling Himalaya, Through Critical Analysis of Slope Instability- A Step towards Rational and Scientific Management of Land, Soil and Water, UGC Sponsored Minor Research Project [F.31210/2005(31.03.2007)]

Mallet, F.R. (1874) On the geology and mineral resources of the Darjeeling District and the Western Duars. Memoir, GSI 11 (1); pp.72.

Manandhar, I.N., Khanal, N.R. (1988) Study on landscape process with special reference to landslides in Lele watershed, central Nepal. Report submitted to Research Division, Tribhuvan University, unpublished, $53 \mathrm{pp}$.

Metteotti, G. (1996) Valutazione del rischio di franosita per unbacino di tipo alpino (in Italian), Ph. D. Dissertation, University of Padova, Italy.

Melnikov, M. and Chensokov, M. (1969) Safety in open cast minning, Moscow: Mir Publications.

MoHA, (2004) Disaster scenario of Nepal (2000-2003). Ministry of Home Affair, Government of Nepal, $157 \mathrm{pp}$.

Montgomery, D.R., Dietrich, W.E. (1994) A physically based model for the topographic control on shallow landsliding. Water Resources Research 30 (4), 1153-1171.

Pethick, J. (1984) An introduction to Coastal Geomorphology, (pp. 73-74) Arnold Pub. London.

Pomeroy, J.S. (1984) Storm-induced slope movements at East Brady, northwestern Pennsylvania. US Geological Survey Bull, vol. 1618, 16 pp.

Schumm, S.A. (1977) Drainage Basin Morphology, Bechmark Papers in Geology, 4, Hutchinsons and Ross, Pennsylvannia: Dowden.

Schwab et al. (2002) Soil and water conservation Engineering (pp.18-47) John Wiley and Sons, Inc. New York.

Skempton, A.W. and Hutchinson, J.N. (1969) Stability of natural slope and embankment section, Proceedings $7^{\text {th }}$ Int. Cong. Soil. Mech. Eng. Mexicom, 291-340.

Starkel, L. (1972) The role of catastrophic rainfall in the shaping of the relief of the Lower Himalaya (Darjeeling Hills). Geogr. Polonica 21, 103-147.

Terlien, M.T.J. (1997) Hydrological landslide triggering in ash covered slopes of Manizales (Columbia). Geomorphology 20, 165-175.

Terlien, M.T.J. (1998) The determination of statistical and deterministic hydrological landslide triggering thresholds. Environmental Geology 35 (2-3), 124-130. 
Terzaghi, K. (1962) Stability of steep slopes on Hard Unweathered Rock, Geothnique, 12, 251-270.

Upreti, B.N. (1999) An overview of the stratigraphy and tectonics of the Nepal Himalaya. Journal of Asian Earth Sciences 17, 577-606.

Upreti, B.N., Dhital, M.R. (1996) Landslide studies and management in Nepal. ICIMOD, Nepal, 87 pp.

Van Burkalow, A. (1945) Angle of repose and angle of sliding friction; An Experimental study, Geol. Soc. America. Bull. 56, 669-707.

Varnes, D.J. (1978) Slope movement types and process. In Schuster R.L., Krizek, R.J. (Eds.), Landslides Analysis and Control. Special Report 176, Transportation Research Board, National Academy of Sciences, Washington D.C, pp.12-33.

White, I.D., Mottershead, D.N., Harrison J.J. (1996) Environmental systems, 2nd ed. London, Chapman and Hall, 616 pp.

Wieczorek, G.F. (1987) Effect of rainfall intensity and duration on debris flows in central Santa Cruz Mountains, California. In: Crosta, G., Wieczorek G.F. (Eds.), Debris flows/ avalanches: processes, recognition and mitigation. Reviews in Engineering Geology, vol. 7. Geological Society of America, pp. 23-104.

Wieczorek, G.F. (1996) Landslide triggering mechanisms. In: Turner, A.K., Schuster, R.L. (Eds.), Landslides: Investigation and Mitigation, Transportation Research Board, Special Report 247. National Research Council, Washington, pp. 76-79.

Wieczorek, G.F., Morgan, B.A., Campbell, R.H. (2000) Debris flow hazards in the Blue Ridge of Central Virginia. Environmental and Engineering Geoscience 6 (1), 3-23.

Wilson, R.C., Wieczorek, G.F. (1995) Rainfall threshold for the initiation of debris flow at La Honda, California. Environmental and Engineering Geoscience 1(1), 11-27.

Zezere J.L., Trigo R.M., Trigo I.F. (2005) Shallow and deep landslides induced by rainfall in the Lisbon region (Portugal): assessment of relationships with the North Atlantic Oscillation. Nat. Hazards Earth Sys. Sci. 5, 331-344. 